\title{
Revisiting Islamic Economics of Nusantara: Conceptual and Legal Perspectives
}

\author{
Moch. Khoirul Anwar ${ }^{1 *}$, Nur Fitroh Febrianto ${ }^{2}$ \\ ${ }^{1,2}$ Department of Economics, Faculty of Economics, Universitas Negeri Surabaya \\ Jalan Ketintang, Surabaya 60231, Indonesia
}

\begin{abstract}
The development of Islam in Indonesia is inseparable from the economy because Islam initially came to Indonesia through trade. The teachings of Islam are embedded through economic activities such as in commerce and agriculture, although not uses Islamic terms specifically. As a result, many people are not aware that their economic activity becomes part of the implementation of the Islamic economics concept. Therefore, this paper aims to examine the implementation of Islamic economics in this country, both in terms of conceptual and formal legal practice implemented by the community. This study based on library research that focused on studying a variety of works of literature about the Islamic economic system and its implementation in Indonesia. Interviews and observation also collect the data to farmers and cattle ranchers that have taken as the sample. Furthermore, the data analysis employs a content analysis method to identify the specific characteristics of the information when data had been collected. The results of this study indicate that some of the Islamic economics concepts has been applied in the Indonesian daily economy activities. This reflects the manifestation of the 33rd Article of the Indonesian Constitution 1945 that emphasizes economic built by the cooperations and kinship principle. In the society who do farming and animal husbandry, for example, people implements "Paron" and "Gaduh" that use the same principles with musyarakah in the Islamic financing system.
\end{abstract}

Keywords: Islamic economics; Nusantara; Joint ventures; Kinship

Paper type: Research paper

*Corresponding author: khoirulanwar@unesa.ac.id

Received: January 26, 2019; Accepted: January 13, 2020; Published: January 20, 2020

Cite this document: Anwar, M. K., \& Febrianto, N. F. (2020). Revisiting Islamic Economics of Nusantara: Conceptual and Legal Perspectives. Al-Uqud: Journal of Islamic Economics, 4(1), 133-145. https://doi.org/10.26740/al-uqud.v4n1.p133-145

Copyright (C) 2020, Al-Uqud: Journal of Islamic Economics http://journal.unesa.ac.id/index.php/jie 


\begin{abstract}
Abstrak: Perkembangan Islam di Nusantara tidak bisa dilepaskan dari perekonomian, karena pertama kali Islam masuk ke Indonesia salah satunya adalah melalui jalur perdagangan. Ajaran-ajaran Islam sering dimasukkan melalui kegiatan-kegiatan ekonomi, baik dalam dunia perdagangan maupun pertanian, walaupun tidak secara spesifik menggunakan istilah-istilah Islam. Akibatnya, banyak masyarakat yang tidak mengetahui bahwa kegiatan ekonomi yang mereka lakukan sebenarnya adalah bagian dari implementasi konsep ekonomi Islam. Oleh karena itu, penelitian ini ingin mengkaji lebih mendalam implementasi Ekonomi Islam di Nusantara, baik dari sisi konseptual legal formalnya maupun praktek perekonomian yang di lakukan di masyarakat.Tulisan ini termasuk dalam katagori studi kepustakaan yang fokus penelitiaannya akan diarahkan pada berbagai literatur yang membahas tentang sistem ekonomi Islam dan konsep ekonomi yang diterapkan di Indonesia. Selain itu, untuk memperkuat data yang dibutuhkan, penelitian ini juga melakukan wawancara dan observasi pada praktek kerjasama yang biasa dilakukan oleh para petani dan peternak sapi. Selanjutnya data tersebut dianalisis dengan menggunakan analisis konten dalam rangka mengidentifikasi karakteristik spesifik pesan atau data yang telah dikumpulkan. Hasil dari penelitian ini menunjukkan bahwa beberapa konsep ekonomi Islam telah diterapkan dalam perekonomian Indonesia. Di antaranya pada tataran konseptual seperti yang ada pada pasal 33 UUD 1945 yang menekankan pada usaha bersama dan berasaskan kekeluargaan. Selain itu, praktek kerjasama di masyarakat dalam bidang pertanian yang biasa disebut dengan istilah "paron" dan peternakan yang biasa disebut dengan istilah "gaduh" merupakan implementasi praktek musyarakah yang diajarkan dalam ekonomi Islam.
\end{abstract}

Kata kunci: Ekonomi Islam; Nusantara; Usaha bersama, Kekeluargaan

\title{
INTRODUCTION
}

The term "Islam Nusantara" creates controversy in society. The argument behind the disagreement of the Islam Nusantara concept is the term tends to classify Islam based the place/geography, such as Islam of Arabic, Islam of Africa, and others. This group can be called a fundamentalist group because it considers culture as separated from Islam, and the character of the Prophet Muhammad is put as the role model who implements Islamic economic in his daily activities(Lutfi, 2016).

Islam Nusantara is a term that represents Islam's existence based on the place. In Arabic, analogy is a form of "mudhof-mudhof ilaih" means "in/on/at". The letter فى (Fiy) which means "in/on/at", so the term of Islam Nusantara means historical Islam in the Nusantara. The letter فى (Fiy) has implicated with the concept of Islam Nusantara so can be understood in terms of furu' (details, branches), not on terms of the interpretation of ushul (roots, principles) (Ismail, 2011). This is very different when Islam Nusantara was interpreted as Idhafah, which has the letter sin), which means "from," so it has a meaning the classification of Islam based on place. The presence of religion is certainly not to eliminate the existence of culture, but it can be applied together as long as it does not violate the Qur'an and al-Hadith (Ridwan et al., 2019). Meanwhile, the negative implication of fundamentalist Islamic groups is that Islam tends to not friendly to society's culture.

The perception of local culture influences educational, political, and social orientation was researched by Albritton (2010), who studied the perception of Muslim communities in Southern Thailand with the relatively strong political 
orientation of Muslims. The Santun Region that uses the Thai language and culture supports the Thai government. Meanwhile, other Muslim societies who use Malay language and cultures such as Narathiwat, Pattani, and Yala, oppose to the Thai government. However, Albritton (2010) explained that these conditions are normal and become a part of ethnocultural.

Islam Nusantara is related to the history of the development of Islam in the Nusantara. Therefore, the study of Islam Nusantara is inseparable from how Islam penetrates the Indonesian society who was predominantly Hindu. Several opinions discuss how Islam initially enters Nusantara. According to Sunanto (2012), the writing of Islamic history in Indonesia was started by an orientalist who had the intention to minimize the role and distance of Islamic values with social life. The difference of opinion about the entry of Islam into the Nusantara is related to the entry period of Islam based on teachings of Islam has started and about the perpetrators of propagators or carriers of Islam to the Nusantara.

Suryanegara (1996) is quoting the opinion of W.F. Stutterheim in his book "De Islam en Zijn Komst In de Archipel" that Islam entered the Nusantara in the 13th AD and spread by Gujarat traders. This opinion is based on the tombstone belonging to the first Sultan of the Samudera Pasai Kingdom, namely Malik AsSaleh, who died in 1297. Meanwhile, another opinion which states that Islam entered the Nusantara is in the 7th century AD. According to Hamka, as quoted by Suryanegara (2012), Islam comes to Indonesia in the first century Hijriyah (between the 7th century to $8 \mathrm{AD}$ ) directly from Arabia with evidence of a busy international shipping lane since around the 7th century AD. The cruise line has the Malacca Strait route connecting the Tang Dynasty in China (East Asia), Srivijaya in Southeast Asia, and the Umayyad Dynasty in West Asia. Therefore, it can be concluded that the spread of Islam in Indonesia has two times, namely the 7th century and the 13th century (Matta, 2014).

The term of "Nusantara" was introduced firstly in 1275 through the Cakrawala Mandala Dwipantara concept by Kartanegara, King of Singashari (Sulton, 2016). Based on the book of Negara Kertagama, the Nusantara territory is a part of modern Indonesian territories such as Java, Sumatra and other Indonesian islands, including the islands in Malaysia and Brunei Darussalam. Historically, the Nusantara is more representing social conditions in Indonesia.

The expansion of Islam in the Nusantara is related to economic factors as Islam entered Indonesia through trade. Also, Islam as a universal religion also not only discusses the aspects of mahdlah worship but also regulates and guides in all aspects of human life in the vertical dimension (habl min al Allah) and horizontal dimensions ( habl min al Nas). Al-Quran, as the primary source of Islamic teachings, contains aqidah, shari'ah, history and ethics (morals). This universality is very significant for the aspects of muamalah, which has an extensive scope so that Islam has relativity and flexibility based on the situation and conditions. This corresponds to the human character that when conducting life, culture, and society, humans will still consider diversity aspects (Hokelekli, 2012).

The values of Islamic teachings are often carried out in economic activities such as trade, agriculture, and animal husbandry in the Nusantara. Nevertheless, these activities do not specifically use the term of Islam because it is part of the 
da'wah by ulama'(Febrianto \& Wahyuni, 2017). Many people do not know that their economic activities become part of the implementation of Islamic economics.

\section{RESEARCH METHODS}

This research uses a qualitative approach with the library research study. This approach is able to comprehensively discuss the comparison of literature on the Islamic economic system with the practice of economic activities that have been applied in Indonesia for long centuries. Furthermore, this approach will emphasize meaning and focus on qualitative data. The primary data has been obtained through interviews and observations with paddy farmers and cattle farmers so that primary data can display the integrity of the phenomenon and the depth of the case. The data analysis employs open-ended and inductive data analysis. This is based on the opinion of Nasution (1996) as the inductive mindset will support the descriptive and qualitative approach of data analysis.

This study applies content analysis by understanding carefully and scientifically about the data content (messages) of communication or phenomenon (Muhadjir, 1990). Holsti (1969) has stated content analysis as a technique for making objective and systematic inference by identifying the specific characteristics of data. Therefore, this study can obtain a perfect understanding and integration between the relations of economic activities that have been carried out with dimensions of Islamic economic literature. Hence, the complexity of the problem can be understood culturally. The existence of a cultural comparison with a literature study is the characteristic of Islamic economic research. Although Islamic economic research does not specify the empirical principles of science, Islamic economic methodology can combine Islamic normative principles and empirical studies (Sadr, 2019).

\section{RESULTS AND DISCUSSION}

The concept of empowerment and development in economics is creating a prosperous and equitable society. This is similar to the social concept in the Nusantara, namely economic empowerment that implemented to realize social welfare for Indonesian people. In Article 33, Constitution 1945, paragraph 1, states that "The economy is structured as cooperation based on the principle of kinship." According to Swasono (2005), the word "economy" is an economic order or economic life-span which includes all forms and structures of economic business and involves all economic agents.

Nusantara is a philosophy that manifested in the culture of Bali Tri Hita Karana, which has a spirit of cooperation to make positive behavior (Sulthon, 2016). The concept of cooperation among economic actors certainly has significant implications for the acceleration of public welfare. In the concept of global welfare, the role of various economic actors is significant, including the government. The government must realize equitable welfare for the people by supporting economic activities of the community, financial transfers, and subsidizing basic needs for the poor (Kosec et al., 2018).

In Islamic values, economic empowerment in society should create prosperity for humans. This economic aspect is essential, in usul alfiqh, it is one of the five 
aspects protected by al-daruriyah al-nas li al-nas, namely religion, soul, reason, descent and wealth (Al-Zuhaili, 1986). According to Al-Jauziyah (1993), economic empowerment in accordance with the objectives of the shari'ah through wisdom and benefit of humans in the world and the hereafter. The benefit of humanity lies in justice, mercy, happiness and wisdom so any action that is contrary to the concept of masalahah should not occur when implementing of Islamic law.

Poverty could harm the stability of peace and security of society, even for someone's faith. Moreover, injustice distribution, deprivation of the rights of some people, exploitation of helpless communities cause poverty. Then, it was very easy for instability in life in society and undermines the value of solidarity and compassion in society. Therefore, the development in Islam has three dimensions, namely individual development, physical development (infrastructure), and social development (Askari et al, 2014). Islam encourages people to exploit their potential (human resources) and natural potential (natural resources). Utilization of selfpotential will lead to human economic empowerment so that it can become a powerful community group and favored by God, as described in a hadith of the Prophet Muhammad (al-Nawawi, 1981).

\section{Cooperation and Family Principles}

The word "cooperation" in Article 33, paragraph 1, Constitution 1945 implies that live in togetherness, cooperation, mutual assistance, and synergy. It is beneficial to organize business entities. Cooperation is widely known as mutualism. This togetherness is reaffirmed in the next sentence "based on the principle of kinship", which shows a mutual economic relationship, brotherhood ( $u k h u w a h)$ which rejects the existence of subordination and exploitation, and supports the provision of prosperity so that this principle can be known as the principle of brotherhood (Swasono, 2005).

A more clearly "cooperation" and "principle of kinship" are based on mutualism and brotherhood. In Islam, these two terms are part of the teachings of ukhuwah, both in the form of ukhuwah Islamiyah (brotherhood of Muslims), ukhuwah bashariyah (brotherhood of human beings), and ukhuwah wataniyah (brotherhood with the government) so that Article 33, paragraph 1, Constitution 1945 has partiality for the poor. In the perspective of Islamic economics, the constitution has a message to eliminate mistakes in the distribution of wealth, as taught by Allah in the Qur'an:

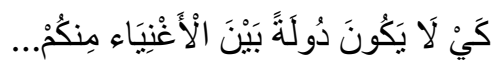

"... so that it will not be a perpetual distribution among the rich from among you. And whatever the Messenger has given you" (Q.S. alHashr:7)

Surah Al-Hashr, Verse 7, implies about God's command to distribute wealth for not only rich people. Therefore, Islam does not forbid the government to intervene through policies in order to balance the economy. When monopolies occur, the price tends to rise and push government intervention to meet the basic 
needs of all people and equalize the wealth distribution (Khan, 2008). Monetary instruments in Islam can be done through zakat as a more holistic policy than a tax because the proceeds of zakat can also be allocated to finance micro-projects given to the poor (al-Jarhi, 2017). However, Allah suggests that Muslims become rich so they can help the poor by paying zakat or taxes (Baidhawy, 2012).

The command of Allah relating to "cooperation" is stated in Al-Qur'an Surah Al-Maidah verse 2:

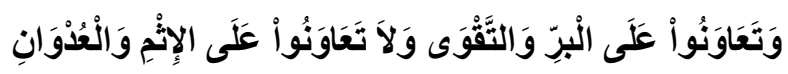

“...Moreover, cooperate in righteousness and piety, but do not cooperate in sin and aggression..."

Ibn Kathir (2000) interpreted verse teaches in the muamalah aspect for cooperation for the common good, both in the world and the hereafter. Ibn Kathir interpreted Surah al-Maidah verse 2 by some hadiths about the command to help others. Al-Maraghi (1946) explained the word "al-Birra" in the above verse is interpreted as multiplying and spreading goodness. Meanwhile, the word "alTaqwa" is interpreted as being afraid of doing something that can cause distress and hurt human beings, both in matters of religion and life affairs. Allah commands human beings to help one another in the good as a part of the social and economic teachings written in the Qur'an. This is based on Islamic economics that covers market phenomena to moral values, culture, and philosophy (Razavi, 2000).

Furthermore, the other verses relating to "kinship," the Word of God in the Qur'an Surah Al-Hujurat verse 10:

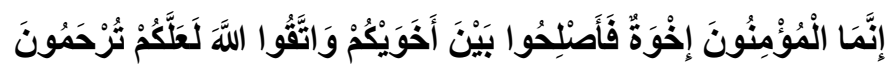

"The believers are but brothers, so make a settlement between your brothers. And fear Allah that you may receive mercy."

Al-Maraghi (1946) asserts that Muslims are brothers because they have the faith to find happiness and eternal peace. Anyone who has faith means relatives and family because Islam promotes equality. The primary bond of Muslims is their belief in Allah. It recognizes Muhammad as the Messenger of Allah, Qur'ran as the Book of Allah, the mandatory of shalah, Ramadhan fasting and other sharia obligations. The implementation of sharia values in modern institutions is encouraging bankers to act honestly and professionally because there is a moral ethic when God bears witness to every human behavior (Al-Jarhi, 2017).

Brotherhood and kinship in Islam are not only limited to ukhuwah islamiyah and ukhuwah wathaniyah, but also ukhuwah insaniyah, which all becomes a universality. Allah said in Al-Quran surah Al-Hujurat verse 13: 


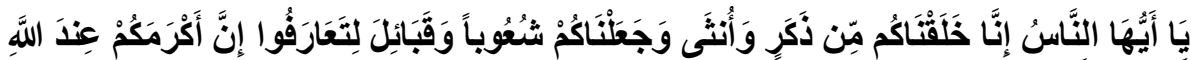

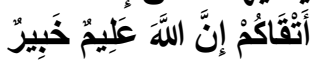

"O mankind, indeed We have created you from male and female and made you peoples and tribes that you may know one another. Indeed, the most noble of you in the sight of Allah is the most righteous of you. Indeed, Allah is Knowing and Acquainted."

This verse confirms in the previous verse that the teaching of a brotherhood of fellow Muslims as mentioned in al-Hujurat: 10, is not only limited to a specific gender, region, or ethnicity. In ijmali, Al-Maraghi (1946) explains that the above verse emphasizes the previous verses which teach brotherhood and kinship, including the prohibition of insulting each other because human nature is derived from the same ancestors. God created humans with different regions and characters so that they could help one another to achieve prosperity and happiness.

The value of helping in kindness and kinship has been implemented in Islamic economics through the concept of syirkah (cooperation). According to Al-Zuhaily (1984), the meaning of musyarakah in Arabic is "al-Ikhtilath," that mixes or combines the assets of two or more people, even though the amount is not the same. The Ulama' Fiqh has a different opinion in interpreting musyarakah. The Fiqh Ulama' concluded that musyarakah is a contract of cooperation between two or more people for a particular business with each person contributing funds or charity (expertise) through profit and risk agreements. The existence of the syirkah concept is undoubtedly an important concern for social communities such as Islamic boarding school or also can be developed by forming modern institutions such as cooperatives or mini bank (Isbah, 2019). Therefore, the syirkah concept is an opportunity to develop business with the principle of cooperation.

The legal basis for syirkah is contained in a hadith qudsi narrated by Abu Dawud and Hakim, namely:

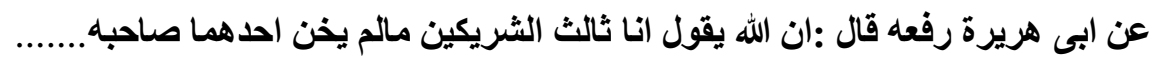

From Abu Hurairah, Rasulullah SAW has said, "Verily Allah AzzaWaJalla said; 'I am a third party from two people who unite as long as one of them does not betray the other."'

This hadith qudsi shows the love of Allah to His servants, who committed partnerships while maintaining trust, togetherness, and avoiding betrayal. Besides, this hadith teaches how to work together to achieve prosperity and happiness based on morals and a sense of brotherhood. Cooperation and kinship taught by Islam aim to provide mercy and affection for the universe, as Allah says: "And I will not send You (O Muhammad) except as a mercy to all the worlds" (Surah Al-Anbiya: 107).

\section{The Implementation of Islamic Economics in Nusantara}

Many people misunderstand the development of the Islamic economy in Indonesia. They consider the development of Islamic economics in Indonesia only manifested 
informal aspects, such as the development of Islamic financial institutions or the development of Islamic economics studies, which began to be taught in state and private universities. Some people still identify Islamic economic as Islamic financial institutions. Islamic financial institutions are only a small part of the concepts that exist in Islamic economics. The concept of the Islamic economy is an institution that structured by God rules, or it means that everything is permissible in terms of muamalah unless there is an argument that prohibits it (Askari et al., 2014).

Long before the emergence of Islamic financial institutions or studies of Islamic economics, Islamic economic in the Nusantara was commonly reflected in the fields of trade, agriculture, or animal husbandry. For example, the system of "Gaduh Sapi" and "Paron Sawah" practiced by the people of Indonesia, especially in rural areas. This concern came from the awareness about the challenge of Islam in Indonesia today, to develop religious discourse and make it get along with local culture (Al-Aharish, 2017).

According to Rahardjo (2004), "Paron Sawah" means a profit-sharing system that becomes a form of a social and economic agreement between the land-owner and the rice field manager with mutually agreed terms. "Gaduh Sapi" and "Paron Sawah" in ushul fiqh included in the study of "urf or law of tradition. Furthermore, Djazuli (2010) stated if 'some groups oppose urf, this does not cancel the position of 'urf. This means that if there are habits that do not conflict with the values of syara 'but some groups disagree with the existence of these habits, then it does not make these habits unlawful.

\section{The System of "Paron Sawah"}

In the culture of village society, one of the agricultural land management cooperation is the landowners who give the freedom of land managers to manage their land with seeds from land managers. The results of land management will be divided 50:50, according to the previous agreement. This form of cooperation is that the owner of the agricultural land does not work his agricultural land, but is left to the manager of the paddy fields, including rice seeds to be planted from the paddy field manager. Agricultural products will be shared about the same amount between the landowner and the rice field manager.

Meanwhile, there is another system that similar to "Paron Sawah," but the landowner provides capital to buy seeds and fertilizer so that the portion of the distribution of agricultural products is $60 \%$ for landowners and the remainder for paddy field manager. Furthermore, the rental-form agreement also becomes an alternative than "paron." It is when the landowner rents his land to the paddy field manager. During the harvest period, the paddy field manager still should divide the yields with a share of $20 \%$ for the landowner and $80 \%$ for the paddy field manager.

The "Paron Sawah" system is usually done with an unwritten agreement that relies on mutual trust between each party who already know about each character and nature. This system enhances inter-community harmony because both the landowners and the land managers get benefits. According to Malik et al. (2018), "Paron Sawah" contains agreement about the rights and obligation of each party, the risk, the duration of the agreement, and the distribution of yields. 
The "Paron Sawah" has been carried out by the Indonesian people as part of the implementation of the Islamic economics concept. Some studies have discussed "Paron Sawah" from the perspective of figh muamalah. The study concluded that "Paron Sawah" was not in conflict with fiqh muamalah method because the terms and pillars had been fulfilled, and the custom did not conflict with Al-Qur'an and Hadith (Primada \& Zaki, 2015).

In shari'ah perspective, the primary requirement of doing muamalah is that this activity is started voluntarily. This is stated in Surah an-Nisa verse 29, which is: "O you who believe! Do not consume each other's wealth illicitly, but trade by mutual consent. And do not kill yourselves, for God is Merciful towards you". Therefore, no coercion is carried out based on consideration of bringing benefits, avoiding mudharat in social life, and maintaining the value of justice.

Moreover, "Paron Sawah" is recognized as a part of a contract known in Islamic economics, namely muzara'ah and mukhabarah. Specifically, the legal basis used in muzara'ah and mukhabarah is the Hadith of the Prophet, which was narrated by Ibn Umar. "That Rasullullah gave the Khaibar land to the Jews on condition that they would work and cultivate it and take some of the results." Supporting this hadith, Imam Bukhari stated, "From Abdullah RA said: Rasulullah has given Khaibar land to the Jews to be managed and he gets share wages from what has been produced."

Imam Ibn Qayyim has explained that the story of Khaibar is the proposition of muzara'ah, and mukhabarah contains how the yield is shared between landowners and land managers. In this contract, Rasulullah cooperated with the Khaibar people. The cooperation lasted until Rasulullah died, and no argument nor act abolished the law. Even the Rashidin Khulafaur also did the cooperation. This model of cooperation is not included in the type of mu'ajarah (hiring people to work), but is included in musyarakah (partnership/cooperation), and this is the same as profit-sharing.

The distribution of the yield of muzara'ah and mukhabarah, should be based on the overall yield of rice fields. This referred to the hadith narrated by Imam Bukhari, Rafi 'bin Khadij said: "Among the Ansar who have the most land is us, so we lease it, part of the land for us and part of the land for those who do it, sometimes part of the land works well, and the others were unsuccessful, so the Prophet Muhammad forbade activities in this way."This hadith explains that the distribution of rice fields should not be based on the distribution of land, but based on the harvest of the overall rice fields in as stated in the previous agreements.

This mechanism is referred to as the aim of the sharia principle, which creates justice, equality, and virtue in every action or policy (Siddiqi, 2009). With the existence of the "Paron Sawah," sharia principle has brought justice to the landowners and land managers because thus each gets the results of what has been agreed upon, creates equality between them because they can get the opportunity to be equally prosperous, and bringing up the virtue as "Paron Sawah" able to bring harmony and trust between people.

In the concept of formal trade, "Paron Sawah" actually needs clear contracts and guarantees from state institutions. This is because the implementation of informal contracts based on family ties or close friends encourages the creation of 
inefficient economic growth and opportunities for fraud (Shachmurove, 2004). The government also should regulate society to create prosperity (Hamzah, 1998). Hence, the government must regulate it to protect the rights and benefits of the two parties.

\section{The System of "Gaduh Sapi"}

"Gaduh Sapi" is a partnership agreement as an effort to raise cattle with a mechanism of vertical cooperation between cattle owners and cattle keepers (Priyono \& Priyanto, 2018). Gaduh Sapi system has been widely practiced in various regions, especially in Bali and NTT (Nusa Tenggara Timur), as the largest supplier of cattle in the Java Region. "Gaduh Sapi" is usually done transparently, honestly, fairly, and consistently. Several studies mentioned that "Gaduh Sapi" has succeeded in developing a beef cattle business in Indonesia. The success of Gaduh Sapi lies in the strength and potential of local resources and innovation in technology and community involvement (Diwyanto \& Priyanti, 2008). Several ways are commonly done by the people of Indonesia related Gaduh Sapi system, namely:

\section{1. "Gaduh Sapi" for Fattening the Beef Cattle}

Cattle owners buy cattle for trading. After the cattle are bought, they handed over to cattle keeper. The raising period is usually three to four months. Cattle keepers bear all costs of feed and raising. When the cattle have been cared for four months, the cattle are sold. The sale proceeds are divided by the same portion share of 50:50 based on the selling price of cattle.

2. "Gaduh Sapi” for Breeding Cattle

The owner buys a mother cow (male and female) to be cared for by a cattle keeper. Cattle keepers bear all feed and maintenance costs. There are two models in revenue sharing:

Type 1: If the cow is giving birth, the first-born calf becomes the property of the owner of the cow, while the second-born calf becomes the owner of the cattle keeper and so forth.

Type 2: If the calf is sold, the proceeds of the sale are divided 50:50 from the sales. If cow owners bear the feed and raising costs, so the sale proceeds are reduced first for the cost of feed and raising, then it is divided by 50:50.

Based on the principles mentioned above, "Gaduh Sapi" can be categorized as the application of musyarakah contract. Musyarakah transactions are based on the willingness of the parties who work together to increase the value of the assets they own together. Based on the Musyarakah principle stated all forms of business that involving two or more parties should combine all forms of their resources (tangible and intangible). The form of a contribution of the collaborating party can be manifested in the form of funds, trading assets, entrepreneurship, skill, property, equipment, or intangible assets, creditworthiness, and other items that can be valued by money.

The practice of cooperation carried out by the community is based on shariah rules. One of the legal basis of cooperation is the hadith narrated by Ibn Majah of Suhaibah that Rasulullah said: "There are three things that are blessed, namely the 
buying and selling that is suspended, giving capital, and mixing wheat with dates for the family, not for sale." Also, Imam Malik also told from A'la Bin Abdur Rahman Bin Ya'kub from his grandfather that he had managed Uthman's wealth, and his profits were divided into two. It is similar to the profit-sharing model. Even though by using the Javanese term "maro bati" (for an equal benefit), in Islam, the division has been valid because it has been through a contract or transaction that is not contrary to the principles of shari'ah and there is a value of percentage, mutual agreement, and mutual benefit. Even though from a quantitative scale, profit is earned without considering raising and labor costs, but this does not cause the transaction to be invalid. Furthermore, from the perspective of Islamic law, the concept of profit-sharing is already valid. However, to fully guarantee to the value of justice, "Gaduh Sapi" needs a model that is economically mutually beneficial. Therefore, "Gaduh Sapi" implemented in Indonesia still needs to be refined, such as the absence of strict sanctions for contract breach between the two parties and how to anticipate the lack of performance of cattle keeper (Sonbait et al., 2011).

\section{CONCLUSION}

Based on the result of the analysis and discussion, this study implies that the concept of Islamic economics has been applied by Indonesian, although they do not specifically mention Islamic economics. The conceptual level, as written in Article 33 of the Constitution 1945 that emphasized cooperation and kinship as the spirit of the Indonesian economy is inspired by the Islamic principle about brotherhood as Muslims and cooperation in doing economic activities. Meanwhile, on a practical level, the cooperation in the agriculture community has reflected in "Paron Sawah," and in animal husbandry has reflected by "Gaduh" are recognized as the implementation of musyarakah in Islamic economics.

\section{REFERENCES}

Albritton, R. B. (2010). The Muslim South in the Context of The Thai Nation. Journal of East Asian Studies, 10(1)61-90. https://doi.org/10.1017/S1598240800003222.

Al-Harish, M. H. M. (2017). Indonesian Islam and Social Challenges Between Moral Cultivation and Intellectual Movement. Journal of Indonesian Islam, 11(2), 551-568. https://doi.org/10.15642/JIS.2017.11.2.551-568.

Al-Nawawi. (1981). Sahih Muslim Bi Sarh Imam al Nawawi, VIII, Beirut: Dar alFikr.

Al-Maraghi, A.M. (1946). Tafsir al-Maraghi.Mesir: Musthafa al-Halaby.

Al-Jarhi, M. A. (2017). An Economic Theory of Islamic Finance. ISRA International Journal of Islamic Finance, 9(2), 117-132. https://doi.org/10.1108/IJEF-07-2017-0007.

Askari, H., Iqbal, Z., Krichene, N., \& Mirakhor, A. (2014). Understanding Development in an Islamic Framework. Islamic Economic Studies, 22(1), 136. https://doi.org/10.12816/0004129.

Al-Zuhaily, W.(1984). Al-Fiqhu al-Islamy wa Adillatuhu Damaskus: Dar al-Fikr. 
Baidhawy, Z. (2012). Distributive Principles of Economics Justice: An Islamic Perspective. Indonesian Journal of Islam and Muslim Societies,2(2), 241266. https://doi.org/10/18326/ijims.v2i2.241-266.

Diwyanto, K. \& Priyanti, A. (2008). Keberhasilan Pemanfaatan Sapi Bali Berbasis Pakan Lokal Dalam Pengembangan Usaha Sapi Potong Di Indonesia. Indonesian Bulletin of Animal and Veterinary Sciences, 18(1), 34-45. https://doi.org/10.14334/wartazoa.v18i1.910.

Djazuli. (2010). Ilmu Fiqh. Jakarta: Fajar Interpratama

Febrianto, N. F. \& Wahyuningsari. (2017). CLC (Centered Learning Circular): Metode Revitalisasi Keilmuan Ekonomi Islam Untuk Kalangan Mahasiswa. Journal of Islamic Economic, (1)1, 83-94, https://doi.org/10.26740/aluqud.v1n1.p83-94.

Huda, N. (2007). Islam Nusantara; Sejarah Sosial Intelektual Islam di Indonesia. Jogjakarta: Ar-Ruzz Media Group.

Hokelekli, H. (2012). Religion, Religiosity, and Research in Psychology of Religion in Turkey. Ilahiyat Studies, 3(2), 223-245. https://doi.org/10.12730/13091719.2012.32.60.

Hamzah, A. (1998). Al-Idarah Al-Islamiyyah Bi Indunisiyya. Indonesian Journal For Islamic Studies. 5(1), 111-147. https://doi.org/10.15408/sdi.v5i1.762.

Ibn al-Qayyim al-Jawziyah.(1993). A’lam al Muwaqi'in, Juz III. Beirut: Dar alKutub al-Ilmiyah.

Ismail, Faisal. (2011). The Nahdlatul Ulama its Early History and Contribution to the Establishment of Indonesian State. Journal of Indonesian Islam, 5(2), 248-282. https://doi.org/10.15642/JIIS.2011.5.2.247-282.

Ibnu Katsir, I.(2000). Tafsir al-Qur'an al-'Adzim. Kairo: Mu'assasah Qartabah.

Isbah, M. F. (2019). External Influence and Supports to Pesantren's SocioEconomic Activism in the Changing Context. Journal of Economics and Business, 2(3), 329-370. https://doi.org/10.22515/shirkah.v4i3.271.

Khan, A.(2008). Kapitalisme di Ujung Tanduk; Tinjauan atas Krisis Global, Krisis Minyak, Krisis Pangan dan Bagaimana Sistem Ekonomi Islam Mengatasinya. Bogor: PustakaThariqul 'Izzah.

Kosec, K., Haider, H., Spielman, D. J., \& Zaidi, F. (2018). Political Competition and Rural Welfare: Evidence from Pakistan. Oxford Economic Papers, 70(4), 1036-1061. https://doi.org/10.1093/eop/gpy013.

Luthfi, K. M. (2016). Islam Nusantara: Relasi Islam dan Budaya Lokal. Journal of Islamicate Multidisciplinary, $\quad 1(1), \quad 1-12$. https://doi.org/10.22515/shahih.v1i1.53.

Matta, M. A. (2014). Gelombang Ketiga Indonesia. Jakarta: The Future Institute.

Malik, M., K., Wahyuni, S., \& Widodo, J. (2018). Sistem Bagi Hasil Petani Penyakap di Desa Krai Kecamatan Yoso wilangun Kabupaten Lumajang. Jurnal Pendidikan Ekonomi, 12(1), 26-32. https://doi.org/10.19184/jpe.v12il.6466.

Moleong, L. J. (2006). Metodologi Penelitian Kualitatif. Bandung: Remaja Rosdakarya.

Muhajir, N. (1990). Metodologi Penelitian Kualitatif. Yogyakarta: Rakesaraseh. 
Naqvi, S. N. H. (1994). Islam; Economic and Society. London And New York: Kegan Paul International.

Nasution, M. E. (2006). Pengenalan Eksklusif Ekonomi Islam. Jakarta: Prenada Media Group.

Nasution, S. (1996). Metode Penelitian Naturalistik - Kualitatif. Bandung: Tarsito.

Primada, B. S. \& Zaki, I. (2015). Tinjauan Mekanisme Kontrak Pengelolaan Lahan Pertanian Berbasis Adat Istiadat Dalam Kajian Fiqh Muamalah (Desa Temu, Kecamatan Kanor, Kabupaten Bojonegoro). Jurnal Eonomi Syariah Teori \& Terapan, 2(11), 954-969. http://.doi.org/10.20473/vol2iss201511pp\%25p.

Priyono \& Priyanto, D. (2018). Kemitraan Penggemukan Sapi Bali Berbasis Sumber Daya Lokal di Wilayah Lahan Suboptimal Nusa Tenggara Timur. Indonesian Bulletin of Animal and Veterinary Sciences, (28)2, 61-68. https://doi.org/10.14334/wartazoa.v28i2.1652.

Razavi, M. B. (2000). A Design For an Islamic Economic System. Iranian Economic Review, 4(4), 8-41. https://doi.org/10.22059/IER.2000.30876.

Rahardjo. (2004). Pengantar Sosiologi Pedesaan dan Pertanian. Yogyakarta: Gajah Mada University Press

Ridwan, B., Syahputra, I., Taringan, A. A., \& Siregar, F. A. (2019). Islam Nusantara, Ulemas, and Social Media: Understanding The Pros and The Cons of Islam Nusantara Among Ulemas of West Sumatera. Indonesia Journal of Islam and Muslim Societies, 9(2), 163-188. https://doi.org/10.18326/ijims.v9i2.163-188.

Sadr, S. K. (2019). The Methodology of Islamic Economics. Iranian Economic Review, 23(4), 897-917. https://doi.org/10.22059/IER.2019.72996.

Sunanto, M. (2012). Sejarah Peradaban Indonesia. Jakarta: Rajawali Pers.

Suryanegara, A. M. (1996). Menemukan Sejarah Wacana Pergerakan Islam di Indonesia. Bandung: Mizan.

Sonbait, L. Y., Santosa, K. A. \& Panjano. (2011). Evaluasi Program Pengembangan Sapi Potong Gaduhan Melalui Kelompok Lembaga Mandiri yang Mengakar di Masyarakat di Kabupaten Monokwari Papua Barat. Bulletin of Animal Science, (35)3,

208-217. https://doi.org/10.21059/buletinpeternak.v35i3.1095.

Siddiqi, M. N. (2009). Maqashid-e Shari'at. Journal of King Abdulaziz University, Islamic Economics, 23(2), 235-244. https://doi.org/10.4197/Islec.28-1.11.

Shachmurove, Y. (2004). Economic Development in the Middle East. PIER Working Paper (4)22, 2-37. https://.doi.org/10.2139/ssrn.548362.

Swasono, S. E. (2005). Indonesia dan Doktrin Kesejahteraan Sosial; Dari Klasikal dan Neo klasikal Sampaike The End of Laissez Faire. Jakarta: Perkumpulan Prakarsa.

Sulton, Ahmad. (2016). Filsafah Nusantara Sebagai Jalan Ketiga Antara Falsafah Barat dan Falsafah Timur. Jurnal Ilmu-Ilmu Ushuluddin, 17(1), 17-28. https://doi.org/10.14421/esensia.v17i1.1275.

.(1986).Usul al-Fiqh al-Islami. Damaskus: Dar al Fikr.

(2012).ApiSejarah,Vol. 1. Bandung: Salamadani. 